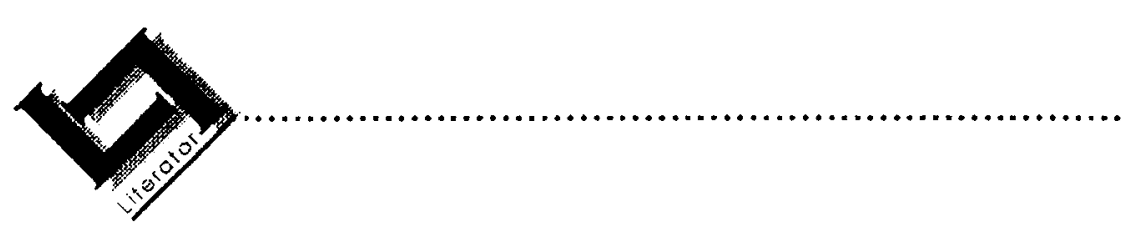

\title{
Translating poetry: Creative art or semantic science? A case study
}

\author{
Carole Beckett \\ School of Language, Culture and Communication \\ Discipline: French \\ University of Natal \\ PIETERMARITZBURG \\ E-mail: beckettc@nu.ac.za
}

\section{Abstract}

Translating poetry: Creative art or semantic science? A case study

There is an on-going debate as to the real value of translation: is it an art or a science? Is the translator engaged in genuine creation or is she merely transliterating the creation of someone else? In order to attempt to resolve this long-standing and thomy problem, this article examines the poet's understanding of the "logos", the creative force of the word and the relationship which exists between the "signifiant" and the "signifie". Extracts from poems by Alan Paton, Victor Hugo and Pablo Neruda senve to illustrate that poetic words not only transmit the poet's experience but actually create it. If the poet is sensitive to the creative nature of language, as these two extracts suggest he should be, it follows logically that a good translator too must be aware of the degree to which language can create, and this perception must be implemented in the subsequent translation. Because only human beings and not machines possess sensitivity, it stands to reason that a machine is incapable of effectively translating the most emotional of literary genres: poetry. So as to illustrate this fact, this article compares and contrasts a computer-generated translation of Paul Verlaine's poem "Chanson d'automne" with three "human-generated" translations. In my own translation, comments and justifications are made as to the choice of a particular word or phrase proposed as translation. The conclusion is reached that translation implies a high degree of sensitivity towards the poet's original intention as well as a collaborative process between poet and translator which results in an entirely new poem which involves as much, but different creativity as the original writing of the poem. 


\section{Translation: art or science?}

The role and the required talents of a good translator as well as the recognition that should be accorded to her work have long formed the basis of an on-going debate. In Translation and Translating, Roger T. Bell notes that "The study of translation has been dominated, and to a degree still is, by the debate about its status as an art or a science" (Bell, 1993:4). Similarly, in her editor's note to Translation: Theory and Practice, Tension and Interdependence, Mildred L. Larson states that "there has been a long-standing discussion of whether translation is science or art" (Larson, 1991:1)

A glance at a dictionary or thesaurus, those indispensable tools of any translator, reflects only too clearly the denigrating perception that the general public and, sadly, fellow academics customarily have of translators: borrowers, copiers, emendors, interpretors, paraphrasers, plagiarists, transposers ... all negative words which fail to give any credit for the original creativity of those engaged in translation.

This criticism would appear to be based on two fundamental conceptions:

- Translation consists merely of providing exact semantic equivalences between a word in the source language (SL) and a word in the target language (TL). Quoting Newmark, Sergio Viaggio observes that "We do translate words, because there is nothing else to translate; there are only words on the page; there is nothing else there" (quoted in Larson, 1991:175). What Viaggo does not clarify is whether one is translating a series of isolated words or rather words as constituent parts of a poetic image.

- This being the case, the translator is in no way engaged in the creating of something new by the act of translating but is merely copying, paraphrasing, transposing etc. As Meetham and Hudson would have it "the aim is to reproduce as accurately as possible all grammatical and lexical features of the 'source language' original by finding equivalents in the 'target language'. At the same time all factual information contained in the original text ... must be retained in the translation" (quoted in Bell, 1993:13).

\section{Types of translation}

A comparative study of different translations of the same text would allow one to examine these concepts so as to judge their validity. But are they all equal? Are they all starting from the same point? In our case study, the answer is "yes" for the original text would be the same. Do they all 
have the same goal? Are they all aiming at the same audience? As Hamlet said, in an entirely different context: "There's the rub".

Some translators specialise in scientific texts: technical, medical, legal, business, commercial, judicial and the like. Scientific language, by the very nature of its field of study, aims at a clarity and precision which is devoid of subjective intrusion and emotion. Those who translate these documents are targeting specialists in a similar field and their aim is the transposition of knowledge from the $S L$ to the $T L$ : the translator is engaged in informational or semantic (meaning-bound) discourse. This domain, for the purpose of this article, does not interest us for. As we have stated in the title, we plan to examine the translation of poetry and for this reason we need to understand how poets perceive of words within the poetic context.

\section{Three interpretations of the creative force of the "logos"}

In his poem "I have approached", written between 1948 and 1949, Alan Paton describes words in the following way:

They do not form themselves into meanings

Unless some price has been paid for them

Unless some deep thing is felt that runs

Like a living flame through their shapes and forms

So that they catch fire and fuse themselves

Into glowing incandescences

Or if the felt thing is deep indeed,

Into conflagrations so that the pen

Smokes in the hand, and the hand

Burns to the bone, and the paper chars

Under the heat of composition (Paton, 1961:17).

This extract highlights two important aspects of the poetic word: firstly, the intimate relationship which exists between the poet and the word which he chooses to convey his meaning; secondly the inherent creative force of the logos.

In his poem "Réponse à un acte d'accusation" (in Les Contemplations), Victor Hugo explains how the Word (logos) calls the vision into being. When God created the world and more specifically light, He pronounced the word Yahi or - the mere utterance of this word caused light to come into being. For Hugo the poetic word possesses the same creative force as the Word of God in that it calls into being the object or the emotion which is named for: "Car le mot, qu'on le sache, est un être vivant" (Hugo, 1969:26). [For the word, let it be known, is a living being.] 
There is a correspondance, in the Baudelairian sense of the word, between the signifiant (that which designates: the word) and the signifie (that which is designated: the object).

Pablo Neruda expresses a similar vision of the word in his poem entitled "La palabra":

Nació

la palabra en la sangre

creció en el cuerpo oscuro, palpitando,

y voló con los labios y la boca.

Luego el sentido llena la palabra.

Quedó preñada y se llenó de vidas.

Todo fue nacimientos y sonidos:

la afırmación, la claridad, la fuerza,

la negación, la destrucción, la muerte

el verbo asumió todos los poderes

y se fundió existencia con esencia

en la electricidad de su hermosura.

[The word

was born in the blood,

grew in the dark body, beating,

and flew through the lips and the mouth.

Later on, the word filled with meaning.

It remained gravid and it filled up with lives.

Everything had to do with births and sound -

affirmation, clarity, strength,

negation, destruction, death -

the verb took over all the power

and blended existence with essence

in the electricity of its beauty] (Tarn, 1975:202-204).

Neruda's poem deals with a poetic vision of the word which, like that of Hugo's, is imbued with a creative life of its own.

From these three extracts, we can deduce that poetic words cannot be taken lightly for they not only transmit (to the reader) the poet's experience but they create it. This precisely is the challenge which faces the translator of poetry for pure equivalences from one language to another (if indeed they exist) do not suffice if one is to convey the original meaning. In this sense, language is often culturally rooted and reflects 
the attitudinal position of the user. A simple illustration will suffice: an Englishman will say: "I have a bad cold" whereas a Frenchman will say: "J'ai un bon rhume". [I have a good cold.] Two expressions which state the same thing but which clearly show two different attitudes.

\section{4. "Chanson d'automne": A computer-generated translation}

Computers, with programmes specifically designed for translation are often used in the translation of scientific texts. I wondered how such a programme would be able to deal with a poem with all its connotative and denotative aspects. Let us study, as an example, Paul Verlaine's well-known poem "Chanson d'automne":

\section{Les sanglots longs \\ Des violons \\ De l'automne \\ Blessent mon coeur \\ D'une langueur Monotone. \\ Tout suffoquant Et blême, quand Sonne l'heure Je me souviens Des jours anciens \\ Et je pleure}

Et je m'en vais

Au vent mauvais

Qui m'emporte

Deçà, delà

Pareil à la

Feuille morte

I asked a colleague who teaches translation at post-graduate level and who is highly computer literate to generate a translation for me. She had been trained using the Systran programme which is used in translating from French to English. The CGT provided the following:

The long sobs

Of the violins

Of the autumn

Wound my heart

Of a monotone

languor.

Very suffocating

And pale, when 


\author{
Sounds the hour \\ I remember \\ the old days \\ And I cry; \\ And I from go away \\ To the bad wind \\ Which carries me \\ Deca, beyond \\ Pareil with the \\ Dead sheet.
}

The intricacies of electronic data processing will forever remain a mystery to me. For this reason I cannot explain or comment on the actual processes which were implemented in order to arrive at the final product. My analysis will, therefore, be restricted to the text with which I was presented.

With no intelligence and even less sensitivity, it is obvious that CGT is incapable of translating this highly evocative poem.

Simple elements such as articles, prepositions, and adverbs have been transposed (for one dare not talk of translation here) into the TL: "of the autumn"; "of a monotone"; "very suffocating"; "and I from go away". The resultant verses are heavy and, quite often, nonsensical. This gobbledegook is particularly noticeable in the entire last stanza: "deçà" being rendered as the equivalent of the English prefix "deca" (meaning ten) found in words like "decathlon" "decasyllable" etc; "pareil" is given as the old English noun "pareil" whose meaning is all but forgotten by modern users of the language: "equal, equality, a mate, a match" (Oxford Dictionary, 1980:1512); "feuille" is translated as "sheet" meaning an "oblong piece of linen or cotton cloth used as an article of bedding" (1980:1970) or a "broad, flat piece of thin material" (1980:1970) such as a sheet of paper. Not only has the CGT divested Verlaine's poem of its highly evocative atmosphere but it has produced a version which is, for the most part, unintelligible despite (or perhaps because of?) respecting the original word order. It is of interest to note as well, particularly in the light of one of the translations which we will study, that the CGT has made no attempt to address the element of rhyme.

The power of the original poem lies, not in the complexity of the words, all of which are simple and easy to understand, but in the mood which is created by the sounds of the words chosen by the poet. We are, after all, dealing with a symbolist poem which seeks to evoke rather than to describe a state of mind. 


\section{5. “Chanson d'automne": Some "human-generated" translations}

Earlier, I mentioned that the aims of the translator will have a marked effect on the way he or she approaches the original text. By way of illustration, I would like to examine A. Watson Bain's translation of "Chanson d'automne" as it appears in the anthology which he edited French poetry for students (Bain, 1963).

Autumn's long sobs

Like viol throbs

Doleful moan

To languor lull

My heart with dull

Monotone

Pallid and low,

When, sad and slow,

Sounds the hour,

Old days recall

I and let fall

Tears in a shower

And go away

Where wild winds play,

And am sped

Now near, now far,

The same as are

Leaves when dead

Whilst Bain does not state what the prevailing criteria for translation were at the time when he did his translation, it would appear that one of his prime objectives is to respect the metre and the rhyme scheme of the original for he duplicates the 4/4/3 rhythm and retains the aabccb rhyme. Whilst one must respect his choice within the parameters of the goal which he has set himself, my contention is that he has totally failed to remain true to what I consider to be perhaps the basic rule of translation: the ability and the intention to convey accurately, from one language to another, both the "forme" and the "fond" of the original.

In "Chanson d'automne" Verlaine uses the device of synaesthesia, one of the most important devices used by symbolist poets, in which one sense impression evokes another sense impression in an endless chain reaction of sensations. He is not describing. He is not stating but is rather creating a complex world of associations similar to that encountered in Baudelaire's "Correspondances". In "Chanson d'automne" we are enjoined to enter into an interwoven network of sense impressions that 
symbolise a particular state of mind: an indefinable and unexplained sense of melancholy.

The translator who wishes to do true justice to Verlaine's poem will not only have to master, to a highly proficient degree, both the SL and the $\mathrm{TL}$, but will also have to be familiar with this creative aspect of what Verlaine calls "la chanson grise" where emotive states of mind are not explicitly described but rather evoked through a series of correspondances.

In his version, Bain would appear to have been totally ignorant of this distinguishing characteristic of Verlainian symbolism or else he deliberately chose to ignore it in favour of prioritising rhythm and rhyme. Whatever the case, the end result is a travesty of translation.

Verlaine's poem, although written 130 years ago, makes use of language which is colloquial and, even today, modern. Bain introduces a turn of phrase and a lexis which are archaic. "Viol" is a 16th and 17th century stringed instrument largely unfamiliar to most contemporary readers. There would seem to be little or no justification for using this word in place of "violin". Likewise "doleful moan", "Old days recall/l and let fall/ tears in a shower", "and am sped". Perhaps it is the second of the three quotations given in the previous sentence that explains this stilted language: "old days recall l".

Apart from the tone of his translation. Bain has sinned by straying from what was originally evoked by Verlaine. His version opens with "Autumn's long sobs". Verlaine conjures up the "sanglots longs des violons". For Bain, these sobs have a specific purpose: to "languor lull". Verlaine's use of synaesthesia would never state so crassly. The sound of the violin arouses in him an equivalent feeling of melancholoy.

In the second stanza, Bain evades the difficulty of finding an appropriate "corresponding" (if I may be permitted the pun!) term for the highly evocative "tout suffoquant" by proposing the banal "low". This is a purely descriptive adjective which, once again, is out of place as regards Verlaine's creative process. Verlaine, quite simply, does not describe. Further adjectives, absent in the original, are introduced pertaining to the sound of the clock which, according to Bain is "sad and slow". Throughout his translation, Bain insists on the purely epithetic quality, thereby totally neglecting the all-important role of synaesthesia in the original poem.

In the light of the theme of this article, Bain's translation can be judged as being neither a science (that which is based on exact measurement or 
calculation) nor an art (the domain where imagination predominates). He has not found "equivalents in the target language" nor has he retained "all the factual information contained in the original text" (Bell, 1993). As for an art? If Bain has created anything it is, in my opinion, a parody.

A second translation of "Chanson d'automne" will allow us to pursue our argument in greater detail. This one was translated by Enid Rhodes Peschel and appeared in Four French Symbolist Poets (Peschel, 1981: 241).

\author{
The sobs long drawn \\ Of the autumn \\ Violins \\ Cause a wound in \\ My heart of monotonous \\ Languorousness \\ Quite choking \\ And pallid, when \\ The hour is tolling \\ I remember \\ The days gone by \\ And I cry \\ And I go off in \\ The evil wind \\ That carries me ahead \\ To this area \\ And that like the \\ Leaf that is dead.
}

As was the case with Bain's translation, Peschel would appear to show little, if any, awareness of the basic symbolist characteristics of the original poem. Her version, in short, is too concrete, too specific. Her translation does not attempt to evoke the poet's state of mind nor does it create the corresponding echoes which are awakened in the mind of the reader. The essential savour of Verlaine's original is totally overlooked.

Peschel's servile reproduction of syntatic structures results in cumbersome verses which bear little resemblance to the ethereal quality of Verlaine's creation. In all, her translation is too literal. How can one possibly justify "the sobs long drawn out" when, in English, adjectives usually precede the noun that they qualify? How is it possible to justify a "wound ... of monotonous languorousness" when the very term "wound" implies pain and physical or mental suffering, a condition which contradicts "languour". What is meant by "quite choking and pallid"? The choice of this adjective is somewhat obscure within the given context. 
I mentioned earlier the awkwardness of Peschel's translation. This is, in part, due to the unwarranted overuse of the definite article as in "the sobs long drawn/ of the autumn", "when the hour is tolling", "I remember the old days" and "carries me ahead ... llike the leaf that is dead". In each case the article could have been omitted thereby enhancing the translation by avoiding the inherent specificity of this syntactical element.

Like Bain, Peschel has treated Verlaine's poem purely as text rather than an evocation of atmosphere or the subtle recreation of emotion and, by so doing, has entirely lost the mood and the underlying meaning of the original.

In an attempt to address and resolve this all-important aspect of translation, particularly as regards symbolist poetry and more specifically the implementation of its tenets in "Chanson d'automne", I would like to propose the following translation:

The lingering lamentations

Of autumnal

Violins

Pierce my heart

With monotonous

Melancholy

Unable to breathe

And ashen-faced

When the hour tolls

I recall

Times past

And I weep

And I drift away

On the restless wind

Which carries me

Hither and thither

Like a

Lifeless leaf

\section{Justification for the proposed translation}

Verlaine's opening stanza relies on the repetitive use of nasal vowels which, according to Cressot and James (1983:33) "quand elles sont en nombre dominant [expriment] la lenteur, la langueur, la mollesse, la nonchalance" (when they dominate by virtue of their frequency [express] slowness, languor, lifelessness, lack of enthusiasm). The English language does not assign this role to nasals quite simply because nasalized vowels do not exist. In order to replicate the mood, in order not 
to betray the poet's original intention, the translator must seek certain subterfuges of style in her translation which will have the same affective effect. For this reason, I have chosen to translate "sanglots longs" by "languid lamentations" for both the liquid "I" and the length of the adjective and noun create a soporific feeling. Furthermore, the "I" is repeated in the words "autumnal" - deliberately chosen for this reason, in preference to "of autumn" - "violin" and "melancholy". Where Verlaine has used assonance in his first stanza to create a mood of listless melancholy, I have used alliteration in order to create the same atmosphere of torpidity.

This first stanza magnificently illustrates the creative power of words to which Paton, Hugo and Neruda referred in the extracts which were earlier quoted. Verlaine names the things he is talking of, but the real magic is to be found in the way that the words are transformed into the sounds of the violin and then into the poet's state of mind: the symbol becomes the symbolised. This precisely is the difficulty which the translator must overcome if her re-creation is to have any value. Words must be "carried over" (to use the etymological sense of the verb translate) from the SL to the TL but so too must the mood and the state of being.

One might argue that my translation of "Blessent" by "Pierce" is a departure from semantic equivalence. Indeed it is, but I justify my choice by reason of the plosive consonant. The initial consonant of the verb "blesser" comes as a euphonic shock and conjures up the unexpected violence of the effect of the melacholic, dulcet sounds of the violin. The mood of the entire first stanza is created by the predominance of nasals and open vowels with the sudden, unexpected, brutal intrusion of a verb which both denotes and, by its sonority, evokes suffering. Similarly, "pierce" evokes an image of force, of sharp penetration, of being deeply affected and is preferred to the more gentle sounding "wound", arguably a closer translation of "blessent".

On a mundane level, a person whose heart has been pierced is, in all probability, mortally wounded. This state (confirmed by the simile of the "lifeless leaf" in the last line) prompts the choice of "unable to breathe" and "ashen faced" as the poet's life blood slowly seeps out of him.

The rendition of "sonne l'heure" by the slightly old fashioned "tolls the hour" has the connotative value of evoking death, for the deep-toned, slow measured strokes of a bell most often used to announce a calamity, a death or a funeral. This choice of verb is therefore in harmony with the images used in the two preceding lines. 
"Times past" as a translation for "jours anciens" has an inherent lilt which is better suited to poetic expression than the more prosaic "old days" and furthermore evokes a feeling of nostalgia which is, after all, one of the principal themes of the poem.

My choice of the verb "weep" as a translation of "pleurer" is dictated by the connotations inherent in the French verb. "Pleurer" evokes not only the plaintive sound which is emitted but also the fact that the person who is weeping is filled with a deep seated emotion, one which could be associated with feelings of regret. Amongst other definitions for "weep", the Oxford Dictionary proposes "to utter with lamentation" (1980:2523). It is precisely this feeling of great sorrow which the verb "weep" so aptly captures. To translate "pleurer" by "cry" would simply not capture the density of allusion. Moreover, "weep" contains an idea of duration. By opting for this translation, with all its nuances, it is possible to re-echo the atmosphere evoked in the opening lines of the poem: "the lingering lamentations", thereby maintaining an internal coherence.

The translation of the verb "s'en aller" poses challenging problems. To use the dictionary equivalent "go", "move" or "leave" (Robert \& Collins Senior Dictionary, 1994:25) is not only flat and unpoetic but is meaningless within the context. In the preceeding two stanzas Verlaine has evoked the image of being mortally wounded, of being close to death and his poem ends with the simile of being like a "lifeless leaf". An alternative translation offered by the Robert and Collins Dictionary is "to die, to sink, to go" (1994:25) These translations can be improved upon by using the euphemistic "drift away" to evoke the poet's death. This choice of the appropriate translation - in keeping with the verb "emporter" - serves as one example only of the need to be constantly aware of the reverberation of meaning, of the necessity to ensure that the hidden meaning of the original is recreated: the poet is not moving towards a specific, designated destination but rather being carried away from his present position.

As was the case in the first stanza, the poet has been totally integrated into the elements: he is of the wind, he is the wind just as he is the "lifeless leaf". The circles in which the wind-swept leaf is whirled are stylistically evoked by the use of alliteration, the same "I" employed in the first stanza of the translation, thereby creating an image of concentricity: through sonoric homophony the poem ends on the same note as that with which it started.

A final note on rhyme. The attentive reader will have noticed that while Verlaine's poem rhymes, I have made no attempt to replicate this melodic device. The reason for this is simple: all too often translators, 
like Bain, will engage in linguistic contortions of a poem in order to imitate or reproduce a rhyme scheme similar to that found in the text on which their translation is based. The resultant effect is, more often than not, grotesque. It is proof that one element only of the poem has become the dominant feature, rather than considering the overall qualities of the entire composition with the resultant evocative effects. Far better, in my view, to see rhyme as one of a variety of poetical devices whose function it is to contribute to the musicality of the poem. Harmony can be created by focusing attention on other poetic devices such as rhythm, assonance, alliteration etc. which will all, in their own but different ways, contribute to the music of the poem.

\section{Conclusion}

To return to the question posed in the title of this article: is translation a creative art or a semantic science? Translation is a complicated process as it involves a linguistic operation as well as a high degree of competency in both the SL and the TL. In this sense, it is certainly a science which demands precise accuracy and which is measurable. But translation is more than this. It also requires an awareness of and a sensitivity to literary and historico-literary theories and their implementation. Once again, this is knowledge which can be learnt and measured for its exactness and which can therefore, arguably, be classified as scientific. But translation goes beyond the competence of finding a word which exactly replicates another in a different language. It goes beyond the ability to recognise a poem as being romantic, parnassian or symbolist and all the creative procedures which this entails. For words and style are essentially the exterior trappings of literary creation. It is precisely here that one can begin to speak of the art of translation. A good translator, a translator-artist will go into the text and re-create the vision transmitted by another. Her work is in no way diminished by the fact that the original idea and its expression in words and metre are not her own. Where the creative aspect comes into its own is in the finding of linguistic and phonological equivalences that recreate and communicate to the reader a new text which reinvents the inherent atmosphere and emotions in a language with which s/he is conversant.

The translator is faced with a series of words which s/he cannot translate by merely transposing their semantic meaning. If she is to remain faithful to the original intention of the poet, she must render the same feelings by recreating similar sonorities. It is here that one is faced with difficulties which are extra-linguistic.

The challenge which presents itself to the serious translator of poetry lies in the degree to which she can work in partnership with the poet. She 
must understand his/her intention (as is explicit in other works or poems for it is seldom that one would attempt to translate a poet of whom one knows nothing). She must be sensitive to the underlying nuances of his/her language. She must be receptive to the atmosphere which is created through the use of the vaste range of stylistic devices open to the poet. Her task is one of collaborative creation which simultaneously acknowledges the original talent of the poet and brings to the fore the individual artistry of her own product. If all these criteria are met, her finished product, whilst remaining faithful to the tone and the intent of the original, will be an entirely new poem, as personal and innovative as the original.

The creative and artistic value of translation has finally been officially recognised by the awarding of the prestigious Whitbread Prize for the year 2000 to Seamus Heaney for his translation of the Anglo-Saxon epic poem Beowolf. The judges stated that Heaney's version is that of "a master poet breathing life into a great work of art which has only been known to a small number of academics".

Translators are certainly not all Nobel Prize winners as is Seamus Heaney. However, as has been stated countless times in the past "Tout est dit, et l'on vient trop tard depuis sept mille ans qu'il y a des hommes et qui pensent" (La Bruyère, 1965:82). (Everything has been said and we are too late since for seven thousand years there have been men who think.) This fact should not act as a deterrent, particularly as regards translation. Once again, La Bruyère's wisdom is applicable: "Horace ou Desprèaux l'a dit avant vous. ... mais je l'ai dit comme mien" (La Bruyère, 100). (Horace or Desprèaux has said it before you ... but I have said it in my way.)

It is precisely the ability to "say it my way", to breathe new life into an existing work of art in order to make it accessible to a widened audience who would be denied that contact because of a language barrier that makes translation an art and not "some kind of second-rate literary activity" (Bassnett, 1997:11).

\section{Bibliography}

Bain, Watson A. 1963. French poetry for students. London : Macmillan.

Bassnett, Susan (ed) 1997. Trans/ating Literature Cambridge : Brewer

Bell, Roger T. 1993. Trans/ation and Translating. London \& New York : Longman.

Cressot, Marcel \& James, Laurence. 1983. Le Style et ses Techniques. Paris

Presses Universitaires de France.

Hugo, Victor. 1969. Les Contemplations. Paris : Editions Garnier.

La Bruyère, Jean de. 1965. Les Caractères. Paris : Garnier-Flammarion. 
Larson, Mildred L. (ed.) 1991. Translation: Theory and Practice, Tension and Interdependence. (Vol. 5.) New York : American Translators' Association, State University of New York.

Paton, A. 1961. "I have approached". (Poem.) Contrast, South African Quarterly, 1(4): , Dec.

Peschel, Enid Rhodes. 1981. Four French Symbolist Poets. Athens : Ohio University Press.

Robert \& Collins Senior Dictionary. 1994. Paris : Harper Collins

Oxford Dictionary.1980. Oxford : Clarendon Press.

Tan, Nathaniel. (ed.) 1975. Pablo Neruda: Selected poems. Translated by Anthony Kerrigan et al. London : Penguin books

Key concepts:

computer-generated translation

"human-generated" translation

source language: required level of language proficiency

target language: required level of language proficiency

translation: art or science?

Verlaine: "Chanson d'automne"

Kernbegrippe:

brontaal - taalvaardigheidsvlak

doeltaal - taalvaardigheidsvlak

mensgeskepte vertaling

rekenaargegenereerde vertaling

Verlaine: "Chanson d'automne"

vertaling: kuns of wetenskap? 
